\title{
Erratum
}

\section{A revisionary synopsis of the Trypetheliaceae (Ascomycota: Trypetheliales) - ERRATUM}

\section{André APTROOT and Robert LÜCKING}

doi:10.1017/S0024282916000487. Published online for the British Lichen Society by Cambridge University Press, 7 December 2016.

A half-couplet was erroneously removed This error has now been rectified in the from page 964 of the article. original online article. The full couplet should now read:

15(13) Pseudostromata sessile with constricted base, upper part black, sharply contrasting with white ostiolar spots; ascospores $80-110 \times 14-18 \mu \mathrm{m}, 13-19$-septate (this synopsis; Fig. $58 \mathrm{E}-\mathrm{I}) \ldots \ldots \ldots \ldots$ Trypethelium sphaerocephalum

Pseudostromata prominent without constricted base, grey (black with thin whitish cover), diffusely contrasting with white ostiolar spots; ascospores $60-70 \times 10-14 \mu \mathrm{m}, 11-15-$ septate (this synopsis; Fig. 58J-L) . . . . . . . . . . Trypethelium ornatum

\section{REFERENCE}

Aptroot, A. \& Lücking, R. (2016) A revisionary synopsis of the Trypetheliaceae (Ascomycota: Trypetheliales). Lichenologist 48 (6): 763-982. 